\title{
Zn-Ni electrodeposition for enhanced corrosion performance
}

\author{
Tolumoye Johnnie Tuaweri ${ }^{1}$, Rhoda Gumus ${ }^{2}$ \\ ${ }^{1}$ Department of Mechanical/Marine Engineering, Niger Delta University, Wilberforce Island, Amassoma, Bayelsa State, Nigeria \\ ${ }^{2}$ Department of Chemical/Petroleum Engineering, Niger Delta University, Wilberforce Island, Amassoma, Bayelsa State, Nigeria
}

\section{Email address:}

tuaweri@yahoo.com (T. J Tuaweri)

\section{To cite this article:}

Tolumoye Johnnie Tuaweri, Rhoda Gumus. Zn-Ni Electrodeposition for Enhanced Corrosion Performance. International Journal of Materials Science and Applications. Vol. 2, No. 6, 2013, pp. 221-227. doi: 10.11648/j.ijmsa.20130206.18

\begin{abstract}
Zinc-Nickel (Zn-Ni) electrodeposition has been carried out using direct current. Cathode current efficiency and deposit thickness were determined by weight measurement method. Influence of current density on the deposition process was also investigated. The morphologies of the deposits were studied using Scanning Electron Microscope and Field Emission Gun Scanning Electron Microscopes. Effect of temperature on the Ni content and morphologies of the deposits was also studied. Energy dispersive spectroscopy (EDX) was utilised to analyse the elemental composition of the deposits. It was found that temperature changes in the bath had a marked influence on the Ni content and morphology of the deposits. Deposit surface profile revealed non-uniform distribution of $\mathrm{Ni}$ in the deposits. Anomalous deposition behaviour was exhibited by the baths and $\mathrm{Ni}$ content of $10-15 \mathrm{wt} \%$ for best corrosion performance was obtained between $60-75 \mathrm{~g} / \mathrm{l}$ of $\mathrm{NiCl}_{2} \cdot 6 \mathrm{H}_{2} \mathrm{O}$. Normal deposition took place at current densities lower than $2 \mathrm{~A} / \mathrm{dm}^{2}$. Deposits with $12 \mathrm{wt} \% \mathrm{Ni}$ exhibited best corrosion performance.
\end{abstract}

Keywords: Zn-Ni Alloy, Electrodeposition, Current density, Corrosion resistance, Morphology

\section{Introduction}

Alloy films electrodeposited onto surfaces can provide desirable surface properties when compared to single-metal films, but alloy deposits can be difficult to apply because of the need to control uniformity of composition, thickness, and microstructure [1]. It is well known that zinc alloys such as $\mathrm{Zn}-\mathrm{Ni}, \mathrm{Zn}-\mathrm{Co}, \mathrm{Zn}-\mathrm{Fe}$ can provide protection for steel against corrosion [2-9] and that the maximum protective ability of $\mathrm{Zn}-\mathrm{Ni}$ is reached with a $\mathrm{Ni}$ content between 10 and $15 \%[2,10,11]$. These alloys are also considered less polluting when compared to cadmium [2, $12,13]$. Zn-Ni alloys can be obtained using plating baths of different compositions and operating conditions, e.g chloride, sulphate, ammoniacal, sulphate-sulphamate, sulphate-chloride, pyrophosphate and cyanide [14]. Most studies on the codeposition of $\mathrm{Zn}-\mathrm{Ni}$ have been made with acid baths which are not suitable for steels with tensile strength greater than $1510 \mathrm{MPa}$ due to their high susceptibility to hydrogen embrittlement [13]. Also, many commercial baths contain ammonium chloride, which causes effluent treatment problems and are undesirable because of the negative environmental impact of ammonia
[14]. The electrodeposition of $\mathrm{Zn}-\mathrm{Ni}$ alloy is generally a codeposition of the anomalous type [15], since the less noble metal $\mathrm{Zn}$ deposits preferentially to Ni. However, the codeposition of $\mathrm{Zn}$ and $\mathrm{Ni}$ is not always anomalous since, at low current densities, it is possible to obtain normal deposition where $\mathrm{Ni}$ deposits preferentially to $\mathrm{Zn} \mathrm{[16].}$ Therefore, there is a transitional current density that has to be reached in order to start anomalous codeposition. Many attempts have been made to explain the anomalous codeposition of alloys, but there is still no universally accepted theory. The theory of anomalous codeposition has been attributed to $\mathrm{pH}$ increase at the cathode surface as it induces zinc hydroxide precipitation, which inhibits $\mathrm{Ni}$ discharge [17]. This theory does not explain the strong inhibition of $\mathrm{Ni}$ reduction observed in the normal deposition region, the high current efficiency during anomalous deposition and the increase in the Ni content of the alloy with increasing $\mathrm{pH}$ [18]. Recently, Zn-Ni codeposition was studied by means of polarization curves and impedance spectroscopy measurements both in chloride [19] and in sulphate baths [18]. The reaction models proposed are substantially similar and involve several adsorbed intermediates. In particular, at low 
cathodic polarisation (normal codeposition) the deposition of nickel-rich alloys was attributed to a mixed intermediate $\left(\mathrm{ZnNi}^{+}{ }_{\mathrm{ad}}\right)$, which catalyses the reduction of $\mathrm{Ni}^{2+}$ ions. At high cathodic polarizations (anomalous codepositon) zinc preferential discharge is attributed to the intermediate $\mathrm{Zn}^{+}$ad, catalyst for the deposition of $\mathrm{Zn}$ rich deposits [12]. The ability to control the deposition of each of these is largely a function of several parameters such as current density, $\mathrm{pH}$, organic additives, buffer capacity, and concentration of solution components. Changes in each of these variables could lead to corresponding changes in the kinetics of electrodeposition, composition and morphology of the coatings, as well as in their physico-mechanical characteristics [20]. Since the range of Ni content in the alloy deposit for maximum corrosion resistance is relatively narrow, it is essential that small changes in operating conditions do not lead to substantial changes in $\mathrm{Ni}$ content from the optimum [14]. The need to optimise these variables to obtain the required optimum deposit composition is crucial. This study therefore, seeks to optimise the deposition parameters essential to obtain the range of nickel percentage in the coatings for best corrosion performance.

\section{Experimental Methods and Materials}

\subsection{Electrolyte Preparation}

The solutions were prepared using deionised water and standard laboratory reagents. The bath formulations used in this study are as follows; (1) $264.5 \mathrm{~g} / 1 \mathrm{ZnSO}_{4} .7 \mathrm{H}_{2} \mathrm{O}, 350 \mathrm{~g} / 1$ $\mathrm{NiSO}_{4} \cdot 6 \mathrm{H}_{2} \mathrm{O}, \mathrm{pH}=3.5-4.0$, (2) $62.5 \mathrm{~g} / 1 \mathrm{ZnCl}_{2}, 60.7 \mathrm{~g} / \mathrm{l}$ $\mathrm{NiCl}_{2} .6 \mathrm{H}_{2} \mathrm{O}, 200 \mathrm{~g} / 1 \mathrm{NH}_{4} \mathrm{Cl}, \mathrm{pH}=3.5$ [14]

\subsection{Determination of Cathode Current Efficiency}

Pre-weighed samples were rinsed with deionised water after plating and dried in a hot stream of air. The dried samples were weighed again to obtain the weight gain. The percentage compositions of individual metals in the deposit were obtained using SEM fitted with an energy dispersive $\mathrm{X}$-ray spectrometer (EDX). The cathode current efficiency was determined using the following expression:

$$
C C E=\frac{\Delta W\left(w t \%_{N i} / M_{N i}+w t \%_{Z n} / M_{Z n}\right) \times 2 F}{j A t} \times 100 \%
$$

Where:

$C C E$ cathode current efficiency, (\%)

$\Delta W$ change in weight after plating, $(\mathrm{g})$

$w t \%_{N i}, w t \%_{Z n}$ weight percentages of $\mathrm{Ni}$ and $\mathrm{Zn}$ in the deposit

$w t \%_{N i}+w t \%_{Z n}=100 \%$

$M_{N \mathrm{i}}, M_{Z n}$ atomic weight of $\mathrm{Ni}$ and $\mathrm{Zn}(\mathrm{g} / \mathrm{mol})$

$F$ - Faraday constant $(96500 \mathrm{C} / \mathrm{mol})$

$j$ - applied current density $\left(\mathrm{A} / \mathrm{dm}^{2}\right)$

$A$ - effective cathode surface area $\left(\mathrm{dm}^{2}\right)$

$t$ - plating duration (second)

\subsection{Coating Preparation}

Coatings were electroplated onto mild steel. Prior to electrodeposition, the mild steel panels were first cathodically cleaned in an alkaline bath containing $25.0 \mathrm{~g} / \mathrm{l}$ of $\mathrm{NaOH}, 25.0 \mathrm{~g} / \mathrm{l}$ of $\mathrm{Na}_{2} \mathrm{CO}_{3}$ and $50.0 \mathrm{~g} / \mathrm{l}$ of $\mathrm{Na}_{3} \mathrm{PO}_{4}$ and etched in 50 vol.\% (S.G 1.18) hydrochloric acid for approximately 20 seconds, washed in running tap water and then in deionised water. These were then transferred immediately into the bath for electroplating to avoid reoxidation of the surface. All the electrodeposition experiments were carried out galvanostatically using DC currents. The anode material in all cases was $99 \%$ zinc foil. Coating morphologies were analysed using Scanning Electron Microscope (SEM) and a Field Emission Gun Scanning Electron microscope (FEGSEM) both fitted with an energy dispersive analysis (EDX) facilities.

\subsection{Neutral Salt Spray Testing}

Neutral salt-spray corrosion investigations were conducted according to ASTM B117 with C and W Equipment Ltd, salt-spray cabinet, model number SF 450CASS under constant humidity conditions, and in a $5 \mathrm{wt} \%$ sodium chloride solution at $35^{\circ} \mathrm{C}$. All coatings tested had a nominal thickness of $8 \mu \mathrm{m}$. The edges of each sample were securely masked with inert tape. Effective surface area of samples exposed to the salt fog was approximately $50 \mathrm{~cm}^{2}$. Time to $5 \%$ red rust was used to describe the level of corrosion resistance of each sample.

\section{Results and Discussion}

\subsection{Effect of Current Density}

Fig.1 shows the relationship between current density, deposit thickness and percentage of $\mathrm{Ni}$ in the deposit. It is evident that the Ni content of the deposit decreases with increasing current density as higher percentages of $\mathrm{Ni}$ were deposited at lower current densities. This observation is in close agreement with reports in literature by other researchers [14, 21-23]. However, in Fig. 2, this gradual decrease was short lived as the percentage of $\mathrm{Ni}$ in the alloys suddenly drops and was constant over a wide range of current densities [20]. A comparative study of two types of baths in the literature [16] also showed the percentage of $\mathrm{Ni}$ being almost constant regardless of the deposition current density within a broad range of current densities, with the chloride bath showing greater current efficiency. A report [14] has also shown that cathode current efficiency for alloy deposition decreased with increasing current density. The difference in trend between Figures 1 and 2 is apparently due to the difference in bath type and composition. A reduction in $\mathrm{Ni}$ content of the deposit with increasing current density reflects the faster kinetics of zinc deposition at greater electrode polarizations. This is an indication that at lower values of current density there is transition from anomalous to normal codeposition. The 
anomalous nature of codeposition has been widely described using the hydroxide suppression model of three regions of codeposition [24]. Although, it is not a generalised model, at lower current densities, normal deposition usually occurs, where the more noble metal deposits preferentially. When the current density is increased, the transition from normal to anomalous deposition occurs with the amount of the noble metal in the deposit falling below the concentration of the metal in the bath. This transition results from the formation of a critical concentration of zinc hydroxide at the cathode surface [21] which apparently hinders the discharge of $\mathrm{Ni}$ ions due to adsorption of zinc hydroxide formed as a result of alkalization near the cathode surface during intense hydrogen evolution.

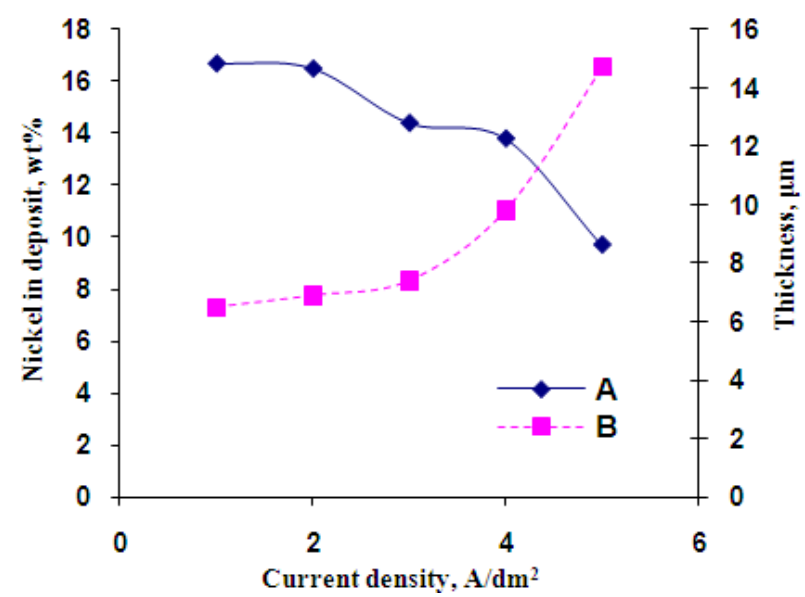

Fig 1. Influence of current density on (A) nickel deposition (B) deposit thickness from a sulphate bath containing $264.5 \mathrm{~g} / \mathrm{ZnSO} \mathrm{Z}_{4} .7 \mathrm{H}_{2} \mathrm{O}, 350 \mathrm{~g} / \mathrm{l}$ $\mathrm{NiSO}_{4} .6 \mathrm{H}_{2} \mathrm{O}$ and $\mathrm{pH} 3.5-4, \mathrm{~T}=25^{\circ} \mathrm{C}$.

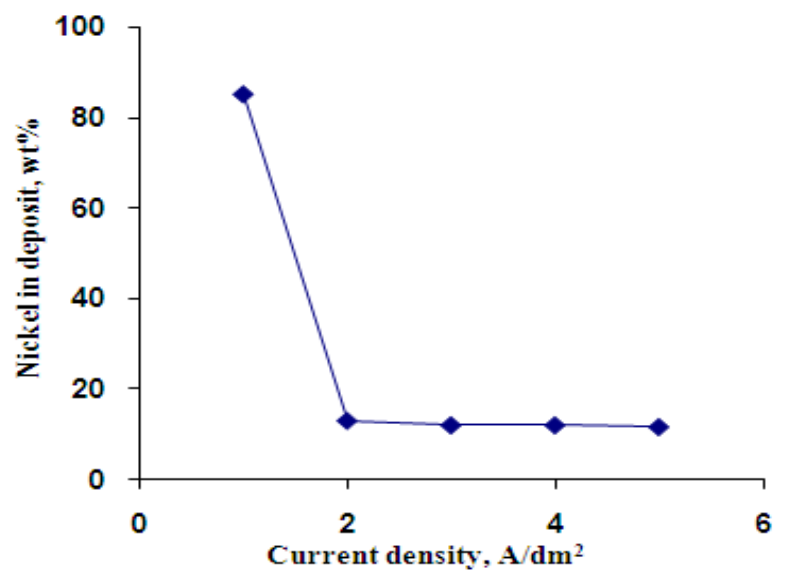

Fig 2. Effect of Current density on the nickel content of the deposit

However, this appears not to be the case at specific bath compositions where $\mathrm{pH}$ values do not reach the values needed for hydroxide formation [2].

\subsection{Effect of Temperature}

Figure 3 shows the influence of temperature on the weight percentage of $\mathrm{Ni}$ in the electrodeposit. These investigations were carried out using a chloride-based acid solution containing $62.5 \mathrm{~g} / 1 \mathrm{ZnCl}_{2}, 60.7 \mathrm{~g} / 1 \mathrm{NiCl}_{2} \cdot 6 \mathrm{H}_{2} \mathrm{O}$, $200 \mathrm{~g} / \mathrm{l}$ and $\mathrm{pH} 3.5$. For the given deposition conditions, it can be seen that as the temperature increased from $25^{\circ} \mathrm{C}$ to $40^{\circ} \mathrm{C}$, the nickel content of the deposit increased from 8.4 $\mathrm{wt} \%$ to $13.4 \mathrm{wt} \%$. This indicates that temperature increase favours Ni deposition. Such behaviour was attributed to the decrease in cathode polarisation and enhanced temperaturedependent kinetics parameters and specifically related to nickel deposition [22]. Also, at higher temperatures redissolution of zinc takes place thereby favouring the deposition of more nickel [23, 25]. An acceptable nickel content for optimum corrosion resistance (10wt\%-15wt\%) as reported by [26] was obtained in a temperature range of 25 to $40{ }^{\circ} \mathrm{C}$. These results are in close agreement with earlier investigations [14, 27] on a chloride bath. It has been reported [14] that with an increase in temperature from 25 to $40{ }^{\circ} \mathrm{C}$, the $\mathrm{Ni}$ content in the deposit increased from $12.5 \mathrm{wt} \%$ to $28.8 \mathrm{wt} \%$. The difference in the range of $\mathrm{Ni}$ percentage increase (8.4wt \%-13.4 wt\%) for the temperature range may be due to slight differences in the bath concentrations. All the data presented in Figure 3 were produced at a current density of $3 \mathrm{~A} / \mathrm{dm}^{2}$, which falls within the optimum range of current densities of 2 to $4 \mathrm{~A} / \mathrm{dm}^{2}$ that produced deposits containing $12 \mathrm{wt} \%$ to $13 \mathrm{wt} \% \mathrm{Ni}$ for a $\mathrm{Ni}$ bath composition with $5 \mathrm{~g} / \mathrm{l}$ to $10 \mathrm{~g} / \mathrm{l} \mathrm{Ni}$ [14]. For the sulphate bath as can be seen in Figure 4, the current efficiency was found to be generally stable at about $70 \%$ over a wide range of deposition time. This is an indication that deposition time does not have any significant influence on the deposition behaviour of zinc-nickel for the conditions investigated.

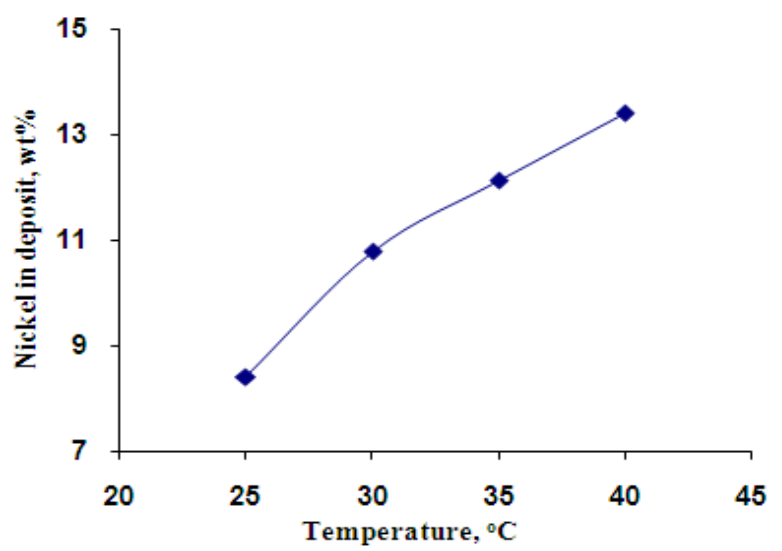

Fig 3. Effect of temperature on the weight percentage of nickel in the $\mathrm{Zn}$ $\mathrm{Ni}$ electrodeposit produced from a solution containing $62.5 \mathrm{~g} / \mathrm{l} \mathrm{ZnCl}, 60.7$ $\mathrm{g} / \mathrm{l} \mathrm{NiCl} 2.6 \mathrm{H}_{2} \mathrm{O}, 200 \mathrm{~g} / \mathrm{l} \mathrm{NH} \mathrm{H}_{4} \mathrm{Cl}, \mathrm{pH} 3.5$

\subsection{Effect of Bath Concentration}

The effect of $\mathrm{Ni}$ ion concentration in the bath on $\mathrm{Ni}$ content in the deposit is shown in Fig. 5. It is obvious that changes in the $\mathrm{Ni}$ content of the deposit took a minimal increasing trend from about $10.4 \mathrm{wt} \%$ to about $13.3 \mathrm{wt} \%$ as the bath concentration of $\mathrm{NiCl}_{2} \cdot 6 \mathrm{H}_{2} \mathrm{O}$ was increased from $60.7 \mathrm{~g} / 1$ to $75.7 \mathrm{~g} / 1$ maintaining an acceptable range of 10.4 to13.3 wt $\% \mathrm{Ni}$ in the deposit for optimum corrosion 
resistance. However, beyond $75.7 \mathrm{~g} / \mathrm{l}$ increase in the $\mathrm{Ni}$ content of the deposit showed a sharp gradient. This is an indication that up to a bath concentration of $75.7 \mathrm{~g} / 1$ $\mathrm{NiCl}_{2} \cdot 6 \mathrm{H}_{2} \mathrm{O}$, the deposition showed an anomalous behaviour. Beyond this concentration, it appears onset of normal deposition begins to take place. The overall trend is consistent with previous works $[12,27]$ in that increasing the $\mathrm{Ni}^{2+}$ ion in the bath results in an increase in the $\mathrm{Ni}$ content of the deposit which supports the theory that the reduction of $\mathrm{Ni}$ ions is controlled by diffusion [27].

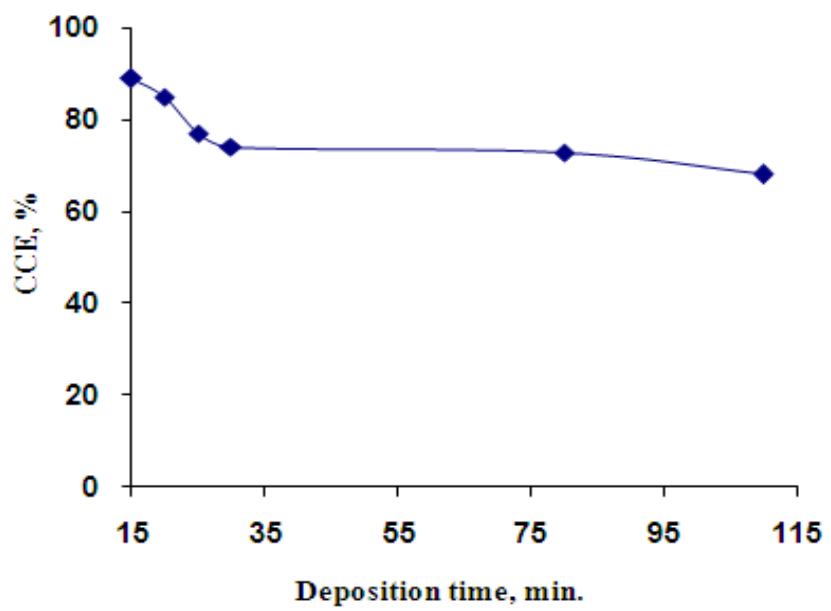

Fig 4. Effect of deposition time on CCE of Zn-Ni electrodeposition from a bath containing $288 \mathrm{~g} / \mathrm{l} \mathrm{ZnSO} \mathrm{S}_{4} 7 \mathrm{H}_{2} \mathrm{O}, 184 \mathrm{~g} / \mathrm{l} \mathrm{NiSO} \mathrm{S}_{4} .6 \mathrm{H}_{2} \mathrm{O}$. Current density $0.3 \mathrm{~A} / \mathrm{dm}^{2}, \mathrm{pH} 3.8, \mathrm{~T}\left(32^{\circ} \mathrm{C}\right)$.

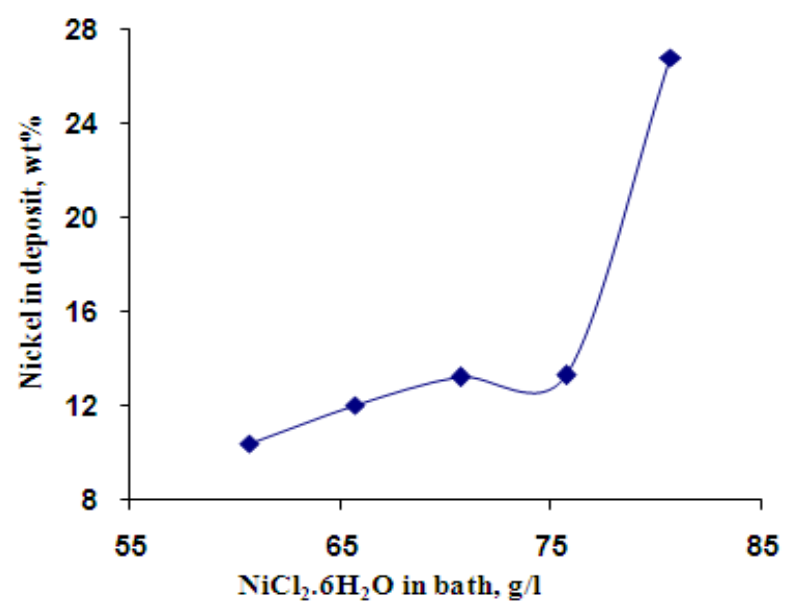

Fig 5. Effect of $\mathrm{NiCl}_{2} .6 \mathrm{H}_{2} \mathrm{O}$ concentration in the bath on the Ni content of the deposit. Current density of $3 \mathrm{~A} / \mathrm{dm}^{2}, \mathrm{pH} 4.5-5.5, \mathrm{~T} 30^{\circ} \mathrm{C}$.

\subsection{Morphology of Zn-Ni Electrodeposits}

Since changes in electrodeposition parameters either increases or decreases the nickel content of the deposit, morphological changes, which are largely a function of the elemental composition of the deposits are inevitable. Coherent and homogeneous coatings obtained with current density $100 \mathrm{~mA} / \mathrm{cm}^{2}$ have been reported [20]. However, above that value deposits appeared less uniform and dendritic along the edges of the sample [20].

\subsubsection{Effect of Uneven Current Distribution}

Current distribution profiling was carried out to determine the distribution of $\mathrm{Ni}$ in the deposits. The results are presented in Table 1. It is evident that, the percentages of $\mathrm{Ni}$ at the centres were higher than at the edges where the current density is thought to be higher due to surface energy differences. These observations seem to compliment previous observations in Fig. 1 where the percentage of $\mathrm{Ni}$ in the deposit decreases with higher current densities. The effects of uneven current distribution and percentage of codeposited elements on the surface of the cathode is further illustrated in Fig. 6a and b. In Fig. 6a, the morphology is made of hexagonal-based pyramidal crystals with each hexagonal crystal separated from it adjacent neighbour at the bases by intergrannular cracks. Such distinct pyramidal crystals are not prominent at the centre of the deposit (see Fig 6b). The formation of clusters of irregularly shaped crystals with obvious intergrannular cracked boundaries is probably due to stress in the process of nucleation and crystal growth typical of $\mathrm{Zn}-\mathrm{Ni}$ electrodeposits. Uneven cathode current distribution and nickel content in the deposit has been reported [23].

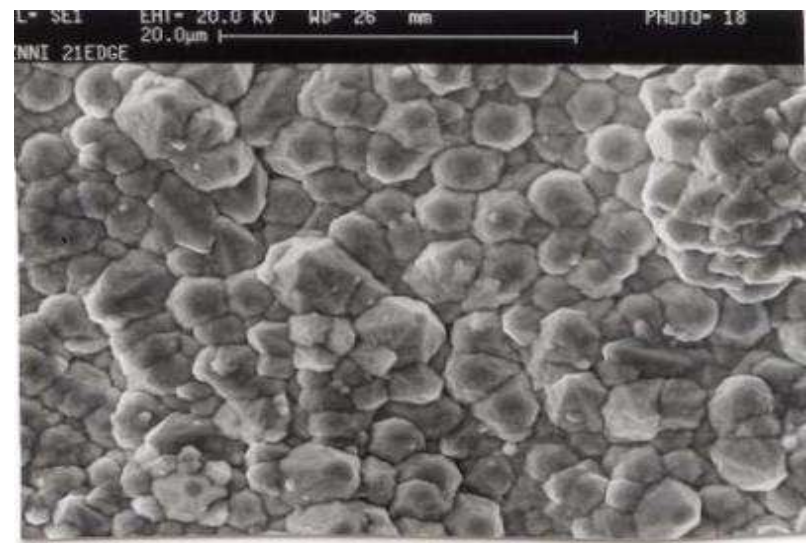

(a)

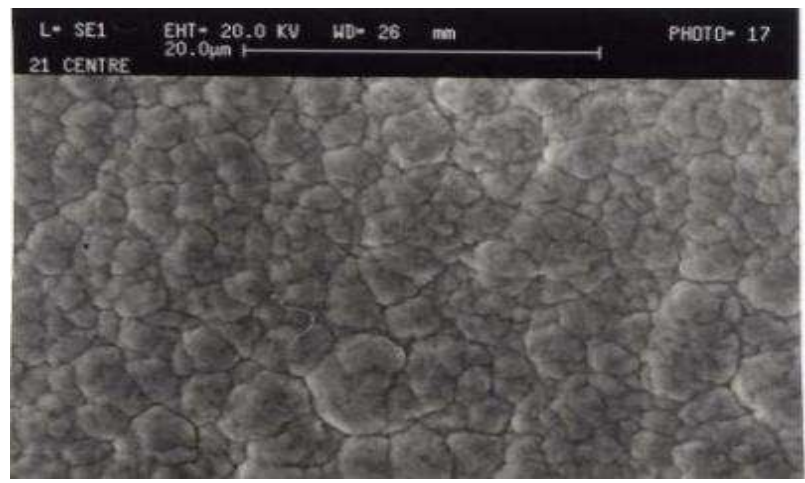

(b)

Fig 6. SEM Micrographs of Zn-Ni electrodeposit with 10.6 wt\% of Ni in the deposit showing (a) edge (b) centre of sample from a bath containing $62.5 \mathrm{~g} / \mathrm{l} \mathrm{ZnCl} 2,60.7 \mathrm{~g} / \mathrm{l} \mathrm{NiCl} 2.6 \mathrm{H}_{2} \mathrm{O}, 200 \mathrm{~g} / \mathrm{l} \mathrm{NH} \mathrm{Cl}_{4} \mathrm{Cl}$. Current density of 3 $\mathrm{A} / \mathrm{dm}^{2}$, pH of $4.5, \mathrm{~T} 30^{\circ} \mathrm{C}$. 


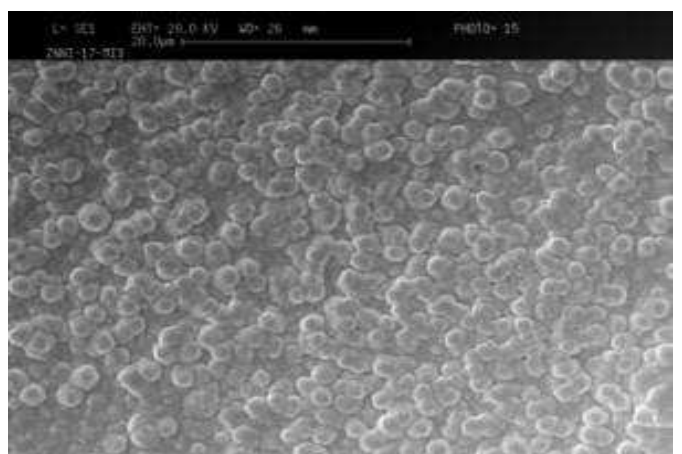

(a)

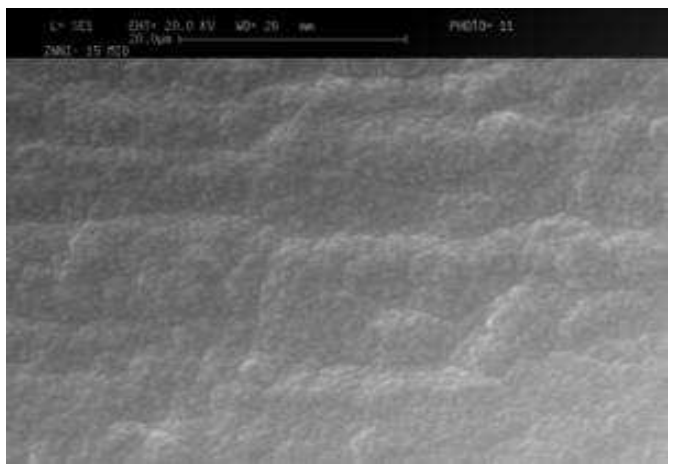

(b)

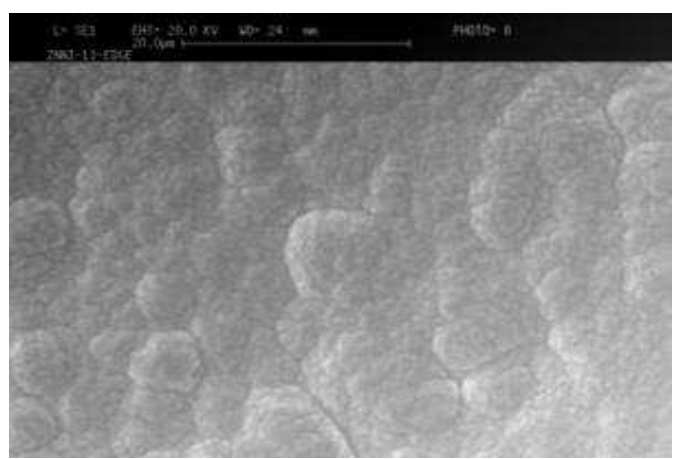

(c)

Fig 7. SEM micrographs of Zn-Ni electrodeposits produced from a bath containing $62.5 \mathrm{~g} / \mathrm{l} \mathrm{ZnCl} 2,60.7 \mathrm{~g} / \mathrm{l} \mathrm{NiCl} l_{2} 6 \mathrm{H}_{2} \mathrm{O}, 200 \mathrm{~g} / \mathrm{l} \mathrm{NH} 4 \mathrm{Cl}, \mathrm{pH} 3.5$ at different temperatures. (a) $\mathrm{T}=25^{\circ} \mathrm{C}$, Ni $7.5 \mathrm{wt} \%$, (b) $\mathrm{T}=30^{\circ} \mathrm{C}$, Ni $12 \mathrm{wt} \%$, (c) $\mathrm{T}=40^{\circ} \mathrm{C}$, Ni $13.4 \mathrm{wt} \%$.

Table 1. Results on the effect of uneven current distribution on the surface composition of the cathode produced from a bath containing $62.5 \mathrm{~g} / \mathrm{l}$ $\mathrm{ZnCl}_{2}, 60.7 \mathrm{~g} / \mathrm{l} \mathrm{NiCl} l_{2} .6 \mathrm{H}_{2} \mathrm{O}, 200 \mathrm{~g} / \mathrm{l} \mathrm{NH}_{4} \mathrm{Cl}, \mathrm{pH} 3.5$ and $\mathrm{T}=30^{\circ} \mathrm{C}$.

\begin{tabular}{llll}
\hline $\begin{array}{l}\text { Zn-Ni } \\
\text { Sample }\end{array}$ & $\begin{array}{l}\text { Ni-wt\% } \\
\text { (Edge) }\end{array}$ & $\begin{array}{l}\text { Ni-wt\% } \\
\text { (Centre) }\end{array}$ & $\begin{array}{l}\text { Ni-wt\%(Edge+ } \\
\text { Centre)/2 }\end{array}$ \\
\hline 19.1 & 9.6 & 10.8 & 10.2 \\
20.1 & 10.1 & 10.8 & 10.4 \\
21 & 10.6 & 10.6 & 10.6 \\
22.1 & 11.7 & 12.3 & 12.0 \\
22.2 & 12.2 & 13.0 & 12.6 \\
23.1 & 12.6 & 13.8 & 13.2 \\
24.1 & 12.4 & 14.1 & 13.2 \\
\hline
\end{tabular}

\subsubsection{Effect of Temperature and Nickel Content}

The morphological changes observed in $\mathrm{Zn}-\mathrm{Ni}$ electrodeposits are largely a function of changes in the nickel content of the deposit associated with changes in the individual parameters. Increase in temperature was met with a corresponding increase in the $\mathrm{Ni}$ content of the deposit (see Fig. 3). Similarly, Fig.7 shows SEM micrographs of $\mathrm{Zn}-\mathrm{Ni}$ electrodeposits produced from an acid chloride bath at $25^{\circ} \mathrm{C}, 30^{\circ} \mathrm{C}$, and $40^{\circ} \mathrm{C}$ with $7.5 \mathrm{wt} \%$, $12 \mathrm{wt} \%$, and $13.4 \mathrm{wt} \%$ of $\mathrm{Ni}$ respectively. At $25{ }^{\circ} \mathrm{C}$ the alloy exhibits regularly shaped nodular grains with gaps between individual grains (see Fig. 7a). This loosely nucleated morphology is an indication that such deposits could be porous and hence poorly corrosion resistant. Interestingly, the percentage of $\mathrm{Ni}$ in this deposit is $7.5 \mathrm{wt} \%$, which is less than the widely reported range of 10 to $15 \mathrm{wt} \%$ nickel $[2,10]$ for optimum corrosion resistance. Apart from the porous and inhomogeneous nature, $\mathrm{Zn}-\mathrm{Ni}$ electrodeposits with percentages of $\mathrm{Ni}$ lower than the optimum range are capable of developing dendritic growths (see Figure 8) which is in good agreement with literature [10, 27]. The temperature increase from 25 to $30{ }^{\circ} \mathrm{C}$, simultaneously increased the $\mathrm{Ni}$ content of the deposit to $12 \mathrm{wt} \%$ with obvious morphological transformations from the predominantly regular grain shaped morphology (see Fig. 7a) to a homogeneously compact morphology as can be seen Fig. 7(b). Such homogeneously compact and crackfree morphologies probably accounts for the excellent corrosion resistance of $\mathrm{Zn}-\mathrm{Ni}$ electrodeposits as it is less likely for corrosive species to migrate through these electrodeposits easily than those with some form of porosity. Lower $\mathrm{Zn}-\mathrm{Ni}$ alloy corrosion rates, when compared to $\mathrm{Zn}-\mathrm{Co}$ and $\mathrm{Zn}-\mathrm{Fe}$, are due to the predominant presence of crystallographic planes with a higher packing density [28]. Further increase in temperature up to $40{ }^{\circ} \mathrm{C}$ was accompanied with a corresponding increase in the percentage of $\mathrm{Ni}$ in the deposit up to $13.4 \mathrm{wt} \%$. However, as evident in Fig. 7(c), initiation of micro cracks or fissures in the coatings accompany the morphological changes and could be as a result of increase in nickel content of the coatings at higher temperatures. The evidence of crack initiation is an indication that at higher contents of $\mathrm{Ni}$, the deposit could become stressed and brittle. Several researchers [27, 29] have made similar observations on changes in $\mathrm{Ni}$ content of the deposit with changes in temperature. For deposits produced at $25{ }^{\circ} \mathrm{C}$, a rough surface morphology was obtained and the structure contained a fine-grain matrix of $\gamma$-phase and coarse $\eta$-phase crystals [27]. However, the deposits produced at $40{ }^{\circ} \mathrm{C}$ showed much smoother surfaces consisting entirely of $\gamma$ phase with nodular fine-grain structure morphology with grain size in the range of $0.5-2 \mu \mathrm{m}$. The slight difference in morphological changes observed in this work and that reported in literature [27] at $40{ }^{\circ} \mathrm{C}$ is probably due to difference in individual bath formulations. Good $\mathrm{Zn}-\mathrm{Ni}$ alloy coatings with compact morphologies and single $\gamma$ phase could be obtained when the deposition temperature is 
fixed at $30-40{ }^{0} \mathrm{C}$ [25]. Nickel content in the deposit is the major parameter controlling the morphology in pulse-plated Zn-Ni alloys [30].

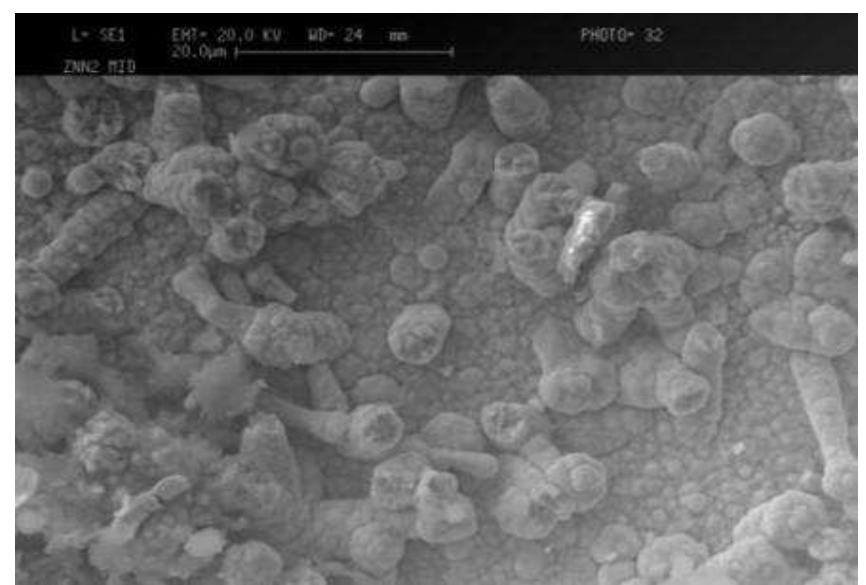

Fig 8. SEM micrograph of Zn-Ni electrodeposit with 9.5 wt\% Ni. produced from a bath containing $264.5 \mathrm{~g} / \mathrm{l} \mathrm{ZnSO}_{4} .7 \mathrm{H}_{2} \mathrm{O}, 350 \mathrm{~g} / \mathrm{l}$ $\mathrm{NiSO}_{4} \cdot 6 \mathrm{H}_{2} \mathrm{O}, \mathrm{pH} 3.5, \mathrm{~T} 22{ }^{\circ} \mathrm{C}$.

\section{Corrosion Resistance}

Fig. 9 shows the dependence of corrosion resistance of the electrodeposits on the content of $\mathrm{Ni}$ in the deposits. The results show that time to $5 \%$ red rust increased with increase in $\mathrm{Ni}$ content up to a maximum at $12 \mathrm{wt} \% \mathrm{Ni}$. Above this point, the corrosion resistance starts to decrease with further increase in $\mathrm{Ni}$. The corrosion performance trend observed in Fig. 9 appears to be a function of the morphology and microstructure of the deposit at specific Ni contents. Comparing Fig. 9 to Figs 6 and 7, it is evident that the morphology of the coating with $12 \mathrm{wt} \% \mathrm{Ni}$ is more compact apparently with more crystallographic planes with higher packing density [28] than others with lower or higher $\mathrm{Ni}$ contents. For $\mathrm{Ni}$ content higher than $15 \%$, the coating quickly becomes nobler than the steel substrate [11] and show a high corrosion current. This is the result of surface $\mathrm{Ni}$ enrichment due to a standard dezincification process [1,11]. Above the optimum range, corrosion potentials are known to increase at higher nickel contents in the coatings [31]. A significant role nickel plays in the Zn$\mathrm{Ni}$ alloy is that nickel slows down the dehydration of zinc hydroxide $\mathrm{Zn}(\mathrm{OH})_{2}$ a product of the corrosion into $\mathrm{ZnO}$. The hydroxide has a lower level of electronic conductivity than the oxide, and corrosion is therefore slower $[1,11]$. Several authors has reported $[1,27,31]$ the presence of different types of phases at different ranges of $\mathrm{Ni}$, in $\mathrm{Zn}-\mathrm{Ni}$ alloys and their influence on the corrosion resistance of these alloy.

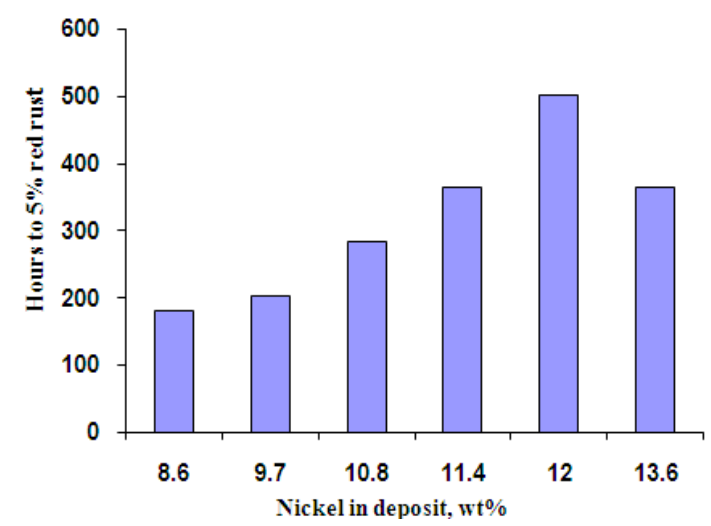

Fig 9. Dependence of Hours to $5 \%$ red rust on nickel percentage in the deposit

\section{Conclusions}

With increasing current density, $\mathrm{Ni}$ content in the coatings was inversely proportional to the coating thickness. $\mathrm{Zn}-\mathrm{Ni}$ electrodeposition was found to be anomalous as the less noble $\mathrm{Zn}$ was preferentially deposited in the majority of investigations. $\mathrm{Ni}$ content of the electrodeposits decreased with increasing current density in practically all cases even though sets of data were produced at different metal ion concentrations and current densities. Salt spray results shows that time to $5 \%$ red rust was longer for coatings with $12 \mathrm{wt} \% \mathrm{Ni}$. The rate of nickel deposition was improved with increase in temperature and $\mathrm{Ni}$ ion concentration in the bath. Ni content of $10-15 \mathrm{wt} \%$ in the coatings for best corrosion performance was obtained between $60-75 \mathrm{~g} / 1$ of $\mathrm{NiCl}_{2} \cdot 6 \mathrm{H}_{2} \mathrm{O}$ for the chloride bath. Morphological changes of $\mathrm{Zn}-\mathrm{Ni}$ electrodeposits were identified to be a function of the Ni content of the deposit, which appears to change with changing deposition parameters. Compositional dissimilarities were found on the surfaces of individual $\mathrm{Zn}-\mathrm{Ni}$ samples especially between the centres and edges of the samples. This is attributed to uneven current distribution on the sample during electrodeposition.

\section{Acknowledgements}

The authors would like to thank the sponsors of this project Bayelsa State Government, Nigeria. Our deep appreciation also goes to Dr. G. D. Wilcox (Loughborough University, United Kingdom) for his invaluable guidance throughout this project.

\section{References}

[1] M.F. Mathias and T.W. Chapman, J. Electrochem. Soc., Vol. 137 (1990) 102.

[2] T.V.Byk,T.V.Gaevskaya,L.S.Tsybulskaya,Surf. Coat. Technol., Vol. 202 (2008) 5817.

[3] L.S.Tsybulskaya,T.V.Gaevskaya,O.G. Purovskaya,T.V.Byk, Surf. Coat. Technol., Vol. 203 (2008) 234. 
[4] A. Maciej, G. Nawrat, W. Simka, J. Piotrowski, Materials Chemistry and Physics, Vol. 132 (2012) 1095.

[5] S.H. Mosavat, M.H. Shariat, M.E. Bahrololoom, Corr. Sci., Vol. 59 (2012) 81

[6] K.R. Sriraman, S. Brahimi, J.A, Szpunar, J.H. Osborne, S. Yue, Electrochimica Acta, Vol. 103 (2013) 314

[7] N. Eliaz, K. Venkatakrishna, A. Chitharanjan Hegde, Surf. Coat. Technol., Vol. 205 (2010) 1969

[8] A. Chitharanjan Hegde, K. Venkatakrishna, N. Eliaz, Surf. Coat. Technol., Vol. 205 (2010) 2031

[9] K.R. Sriraman, H.W. Strauss, S. Brahimi, R.R. Chromik, J.A Szpunar, J.H. Osborne, S. Yue, Tribology International, Vol. 56 (2012) 107

[10] M. Benballa, L. Nils, M. Sarret, C. Muller, Surf. Coat. Technol., Vol. 123 (2000) 55

[11] M. Gavrila, J.P. Millet, H. Mazille, D. Marchandise, J.M. Cuntz, Surf. Coat. Technol., Vol. 123 (2000) 164.

[12] G. Roventi, R. Fratesi, R.A. Della Guardia and G. Barucca, J. Appl. Electrochem., Vol. 30 (2000) 173.

[13] A. Conde, M.A. Arenas, J.J. De Damborenea, Corr. Sci., Vol. $53(2011) 1489$

[14] A. Abibsi, J.K Dennis and N.R Short, Trans. Inst. Met. Finish., Vol. 69 (1991) 145

[15] A. Brenner, "Electrodeposition of Alloys" vol. I and II, Academic press, New York and London (1963)

[16] J.B Bajat, M.D. Maksimovic, V.B. Miskovic-Stankovic, S. Zec, J. Appl. Electrochem., Vol. 31 (2001) 355

[17] S.S Abd El Rehim, E.E Fouad, S.M.A. El Wahab and H.H Hassan, Electrochim. Acta, Vol. 41 (1996) 1413
[18] F.J. Fabri Miranda; O.E Barica, O.R. Mattos and R. Wiart, J. Electrochem. Soc., Vol. 144 (1997) 3441

[19] E. Chassaing and R.Wiart, Electrochim. Acta, Vol. 37 (1992) 545

[20] R. Fratesi, G. Roventi, J. Appl. Electrochem., Vol. 22 (1992) 657

[21] M. Simmons, Ph.D Thesis, Loughborough University, 2001.

[22] H. Ashassi-Sorkhabi, A. Hagrah, N. Parvini-Ahmadi, J. Manzoori, Surf. Coat. Technol., Vol. 140 (2001) 278

[23] H. Young Lee, S. Gyu Kim, Surf. Coat. Technol.,Vol. 135 (2000) 69

[24] H. Dahms and I.M Croll. J. Electrochem. Soc., Vol. 112 (1965) 771

[25] X. Qiao, H. Li, W. Zhao, D. Li, Electrochimica Acta, Vol. 89 (2013) 771

[26] S. Rajendran, S. Bharathi, T. Vasudevan, Trans. Inst. Met. Finish.; Vol. 78 (2000) 129

[27] A.M Alfantazi, J. Page, U.Erb, J. Appl. Electrochem., Vol. $26(1996) 1225$

[28] R. Ramanauskas, P. Quintana, L. Maldonado, R. Pomes, M.A. Pech-Canul, Surf. Coat. Technol., Vol. 92 (1997) 16

[29] A.M Alfantazi, G. Brehaut, U.Erb, Surf. Coat. Technol., Vol. 89 (1997) 239

[30] A.M Alfantazi, A.M El-sherik, U.Erb, Scripta Metallurgica et Materialia, Vol. 30 (1994) 1245

[31] H. Park and J.A Szpunar, Corr.sci., Vol. 40, (1998) 525 